\title{
What Aspects of a Board's Work are Really Important?
}

\section{Tor Brunzell*}

School of Business, Stockholm University, Sweden

Much has been said and written about how a corporate board of directors should perform its work to best fulfill its designated role. However, a board has multiple tasks, and therefore, all efficient-minded chairmen and CEOs should ask the following question:

\section{What Aspects of the Board's Work are the More Important, and What Aspects are Less Important?}

In this editorial article, I will discuss what chairmen and CEOs perceive to be the most and least important aspects of their board's work for a high-quality outcome. I focus on the chairman and CEO because they are the two most important persons affected by their board's work, but they have different roles and perspectives. The chairman leads the board, while the CEO leads the company's daily operations.

How should we attempt to answer the following question: which aspects of the board's work are more important and which are less important? The most direct method is to ask chairmen and CEOs. Therefore, I will base my discussion on data from a questionnaire sent to Nordic listed companies that asked chairmen and CEOs how they perceive different aspects of the work on the board they serve. The respondents responded on a 1-5 Likert-scale. An optimal model is estimated for each working aspect, starting with an overall satisfaction question.

\section{What Does the Board Do?}

The board of directors is the top body within a company and is consequently responsible for the company's all activities. The single goal of a company in a market economy is to maximize shareholder value, and the board's main task is to create an effective organization that will succeed at that goal. The board of directors is the linking body in the relationship between all stakeholders in the company. Furthermore, the relationship between those considered to be the key stakeholders of the company - the shareholders, the board of directors, and the management group - are regulated by the law, the company charter, formal policy and other directions given at shareholder meetings. In several excellent books, the authors present key tasks that the board of directors should master. Harper [1] states that the tasks that the board should address are those essential for the ongoing prosperity of the company, Bowen [2] states that all boards serve eight principal functions, Tricker [3] states that the function of the board may be divided into four functions, Leblanc and Gillies [4] state that it is difficult to generalize what the board of directors do because it can significantly vary between companies; and the godfather of the modern corporate governance, Sir Cadbury [5], says that the board's function is to state the company's aims and objectives and to ensure that they are achieved.

\section{After Reading the Books and Articles on a Board's Work, The Question Remains: What Aspects of a Board's Work are Really Important?}

\section{Sample and methodology}

This study is based on a research conducted on Nordic listed companies with a questionnaire targeting the chairmen and CEOs.
The questionnaire was sent out in December 2007 and closed in June 2008, targeting 780 chairmen and 780 CEOs. The response rate was 20.3 percent for Chairmen and 19.1 percent for CEOs.

In the questionnaire, the chairmen and the CEOs were asked how they perceive the quality of different aspects of their board's work. The respondents responded on a Likert scale of 1 (strongly disagree) to 5 (strongly agree). The questionnaire began by asking a broad question about the quality of the board's work in general and then asked several questions about the respondents perception of specific aspects of the board's work, such as the board's decision making; whether the board has a clear understanding of financial and non-financial issues; whether the board carries out its work efficiently; and how functional the boundary is between owners, the Board, and management. These aspects of the board's work are complemented by monitoring and implementing strategic aspects, such as whether the respondent believes that the board actively reviews the business plan, strategy, objectives, and budget; whether the board actively discusses business strategy; how pleased the respondent is with the board's discussion of the company's short-term development and long-term development, respectively. Furthermore, the respondents are asked about different aspects of the board's composition, including broad composition, sector competence, adequate knowledge of current financial issues, and sufficient representation by gender, and depth in their network of contacts.

The optimal models are estimated by stepwise, ordered probit models. The first model has as the dependent variable the broadest question "How do you perceive that the board work in general". All other aspects of board work and board composition are included as independent variables in this model. The aspects/variables that are included in the first optimal model will then be tested for their own optimal models, where they become the dependent variable. A variable that has been chosen as a dependent variable is then excluded from the sample. This process will continue until all aspects/variables have been included in an optimal model. While the work aspects/variables are excluded, the composition aspects/variables are not. This is because I would like to study only the working aspects/variables. The model that is chosen as the optimal model is the model that shows the highest pseudo R-squared value, and all the independent variables are significant.

\section{Results}

The questionnaire asked what aspects of the board's work is more

*Corresponding author: Tor Brunzell, Assistant Professor, School of Business, Stockholm University, USA, Tel: +46-8-161181; Fax: +46-8-6747440; E-mail: TB@fek.su.se

Received April 03, 2012; Accepted April 04, 2012; Published April 07, 2012

Citation: Brunzell T (2012) What Aspects of a Board's Work are Really Important? J Bus \& Fin Aff 1:e109. doi:10.4172/2167-0234.1000e109

Copyright: @ 2012 Brunzell T. This is an open-access article distributed under the terms of the Creative Commons Attribution License, which permits unrestricted use, distribution, and reproduction in any medium, provided the original author and source are credited. 
and less important to the board's work, in general. The starting point is the overall question about "board work in general" and what affects it. A stepwise, ordered probit model is applied to the overall question as the dependent variable, and all other aspects of the board's work are independent variables. Below, I will only list the statistical results for the first model for the chairmen and the CEOs, respectively. For the models that follow, I will only provide the aspects/variables without listing the statistics.

\section{Chairman}

The optimal model for the Chairman consists of the two work aspects and single composition aspect:

\begin{tabular}{|l|l|}
\hline Variables & Coefficient (z-score) \\
\hline How the Board makes decisions & $1.248(4.71)$ \\
\hline Is the work of the Board carried out efficiently & $1.406(5.98)$ \\
\hline Broad composition & $0.617(2.93)$ \\
\hline Wald Chi2 & 77.15 \\
\hline Pseudo R2 & 0.5518 \\
\hline OBS & 153 \\
\hline
\end{tabular}

Furthermore, in the stepwise, ordered probit regression, with the chairmen's perception of the board's decision-making as the dependent variable, the following variables are included in the optimal model: the board's discussion of the short-term and long-term development; the board's clear understanding of the non-financial (or qualitative) objectives; and the functionality of the boundary between owners, board, and management. Also included in the optimal model are the board's broad composition and depth in the board's network of contacts.

In the optimal model, where the dependent variable is the chairmen's perception of whether the work of the Board is carried out efficiently, I find exactly the same explanatory variables as the previous model, except that the variable for whether the board has a sufficient network of contacts is excluded.

For the next level model, we have the remaining three aspects/ variables. The aspects/variables concern whether the board actively discusses business strategy and actively reviews the business plan, strategy, objective, and budget. The third aspect/variable is the board's clear understanding of financial (or quantitative) objectives.

\section{CEO}

Using a stepwise, ordered probit regression, with the variable "board work in general" as the dependent variable, I found (based on the CEO perceptions) that the optimal model consists of four work aspects and a single composition aspect:

\begin{tabular}{|l|l|}
\hline Variables & Coefficient (z-score) \\
\hline How the Board makes decisions & $0.979(5.46)$ \\
\hline $\begin{array}{l}\text { How the Board discusses the Company's short-term } \\
\text { development }\end{array}$ & $0.918(3.11)$ \\
\hline $\begin{array}{l}\text { Actively reviews the business plan, strategy, objective, and } \\
\text { budget }\end{array}$ & $-0.380(-2.39)$ \\
\hline The board has a clear non-financial objectives/qualitative & $0.745(4.18)$ \\
\hline Broad composition & $0.514(3.17)$ \\
\hline Wald Chi2 & 93.18 \\
\hline Pseudo R2 & 0.4848 \\
\hline OBS & 146 \\
\hline
\end{tabular}

In the following four optimal models the remaining aspects of the board's work are included in at least one model.

\section{Discussion}

In this study's sample - Nordic listed firms - the chairmen and CEOs are always separate individuals. The chairman may only lead the board, while the CEO may only lead the daily operations of the firm. The board members are elected by the shareholders, and the chairman is elected from among these board members. The CEO may either be or not be a board member. If the CEO is not on the board, he/she will attend all the board meetings as the sitting CEO.

The chairman and the CEO obviously have different roles in and perspectives of the board's work. The chairman is chosen on the mandate of the shareholders and is therefore the advocate for shareholders' issues, such as dividends and bonus programs. The CEO is in charge of the daily operations of the company and has more focus on developing issues, such as products, customers, markets, investments and initiating the strategic plan. The chairman is responsible for the board's work, which includes acquiring relevant internal company information for the board, and thus, the board can help the company to develop shareholder value. The CEO provides the board with relevant information, so they can act and make decisions.

The agenda for the board meetings is discussed between and assembled mainly by the chairman and the CEO. However, it is the chairman who has the final say on the agenda, while it is the CEO who provides the board members with information. This means that the chairman and the CEO more or less have a monopoly of information on the board, where the other board members are left basically to the board agenda and information provided to the board. The CEO commonly has some maneuverability in assembling the agenda; he/she may chose when issues should be placed on the agenda.

For both the chairmen and the CEOs, the board's decisionmaking ability is most important. This may seem natural because both the chairman and the CEO are dependent on the decisions made by the board. The chairmen also find that it is most important that the board's work is carried out efficiently, while this variable is not equally important for the CEO. The chairman is responsible for the work, and consequently, it is important that the work is moving forward with a focus is on the "right" issues and that little effort is wasted. Review and discussion may be a consequence that the board is focusing on the right issues; a variable that the chairman otherwise finds comparably less important.

The aspect - the board's review of the business plan, strategy, objective, and budget - is commonly discussed once a year. The CEO is responsible for putting together the strategic development documentation for the company and is responsible for implementing the strategic plan. Interesting is the result that the CEO believe that the more the board actively review the business plan, strategy, objective, and budget the less well does the board perform its work in general. The CEO views this work as a primary input for the board's work, while the chairman views strategic planning as an output of the board's work. The reason the chairman views the review as output is that reviews are constructed on instructions given by the board. The standard of the instructions depends on how efficiently the board works (the right questions are asked), and the efficiency will lead to discussions and issues that will be reviewed. Important input to the review is the board discussion of the company's short-term development, which the CEO regards as relative important. Both the chairman and the $\mathrm{CEO}$ view the board's discussion concerning the company's long-term development to be comparably less important. The subject seems to be seldom discussed and is commonly brought up as a presentation by the CEO. 
Both the chairman and the CEO believe it is more important that board members understand non-financial issues than financial issues; this is because it is considered more important that the board members understand the company business, such as product development, market development, customer behavior, etc. Company business is considered to be more complex and requires more skills than the understanding of financial issues. Financial issues are more supported by expertise and stated theories.

In conclusion, there is a high level of complementary opinions, with some differences, in what the chairmen and the CEOs find to be the most important aspects of a board's work. The latter is largely natural because people seem to overrate the importance of their own work. However, both agree that the important part of board work is what results from it. Here, the CEO is extremely important as a communicator of the results of the work both internally and externally.

\section{References}

1. John H (2007) Chairing the Board: A Practical Guide to Activities and Responsibilities. Kogan Page Publishers, London.

2. Bowen WG (2008) The Board Book: An Insider's Guide for Directors and Trustees. W W Norton Company, New York.

3. Bob T (2009) Corporate Governance. Principles, Policies and Practices. Oxford University Press, Oxford.

4. Leblanc R, Gillies J (2005) Inside the Boardroom: How boards really work and the coming revolution in corporate governance. John Wiley and Sons Ltd Mississauga, Canada.

5. Cadbury A (1995) The Company Chairman (2ndedn) NJ: Prentice Hall. 